BIOREMEDIATION AND TOXICOLOG O

\title{
Kidney Indices and Serum Electrolytes of Diabetic Patients Attending Federal Teaching Hospital Gombe
}

\author{
Aishatu Bello ${ }^{1 *}$, Ibrahim Abubakar ${ }^{1}$, Sadisu Abubakar ${ }^{1}$, Sani Adamu Manga ${ }^{2}$ and Modu Solomon ${ }^{3}$ \\ ${ }^{1}$ Department of Biochemistry, Gombe State University, P.M.B. 127, Gombe State, Nigeria. \\ ${ }^{2}$ Department of Chemical pathology, Federal Teaching Hospital Gombe, 74XQ+H9R, 760253, Gombe, Nigeria. \\ ${ }^{3}$ Department of Biochemistry, Modibbo Adama University, P.M.B. 2076, Yola Adamawa State, Nigeria. \\ *Corresponding author: \\ Aishatu Bello, \\ Department of Biochemistry, \\ Gombe State University, \\ P.M.B. 127, \\ Gombe State \\ Nigeria. \\ Email: belloaisha245@gmail.com
}

\section{HISTORY \\ Received: $23^{\text {rd }}$ Aug 2021 \\ Received in revised form: $14^{\text {th }}$ Oct 202 Accepted: $14^{\text {th }}$ Nov 2021}

\section{KEYWORDS}

\section{Diabetes}

Diabetic nephropathy

Body Mass Index

Electrolytes imbalance

Gombe

\begin{abstract}
Glucose levels in the blood are elevated because the pancreas' b-cells produce less insulin or are more resistant to the hormone's effects. Diabetes mellitus is a persistent metabolic condition. Insulin is linked to long-term difficulties in the metabolism of carbohydrates, fats, and proteins. The objective of this study was to determine kidney indices and serum electrolytes of diabetic patients attending Federal Teaching Hospital Gombe, Gombe State. In total, A total of 240 subjects were used for the analysis ( 200 diabetic and 40 control subjects) and were divided based on their ages and gender Face to face inter-view was used to collect the data and other possible clinical data associated with diabetes mellitus. Fasting venous blood sample was collected to assess serum kidney indices, weight and height were recorded. The result shows individual kidney abnormalities of elevated serum creatinine and urea, elevated level of chloride and reduced sodium and bicarbonate level, according to gender and age groups. Gender, aging, higher body mass indexes (BMI), kidney indices abnormalities and electrolytes imbalance, were the risk factors associated with diabetes mellitus that led to diabetic nephropathy which can increase morbidity and mortality in diabetes mellitus. Effective control of blood sugar can stop or prevent the progression of diabetes mellitus to all these complications.
\end{abstract}

\section{INTRODUCTION}

Approximately $2 \%$ to $3 \%$ of the population [1] has diabetes, making it the third biggest cause of mortality in many developed nations, behind heart disease and cancer. Nowadays, people not only suffer from diabetes, but also from the complications that arise as a result of the condition. There are several organs in the body whose activities might be adversely affected by these problems [2]. Some patients with diabetes develop diabetic kidney disease (diabetic nephropathy). The glomeruli, the kidney's filters, are destroyed in this situation. In response, the kidneys 'leak' excessive amounts of protein into the urine.

Albumin is the major protein that escapes from injured kidneys. ESRD (end-stage renal disease) is the most prevalent cause of diabetes in most regions of the globe. Increased involvement of other organs and worse death rates in diabetes individuals are both caused by kidney disease [3]. Albumin is detected in urine only in trace amounts in people with healthy kidneys. One of the most common early signs of kidney impairment caused by diabetes is a rise in the quantity of albumin in the urine. In persons with diabetes, elevated blood sugar (glucose) levels have been linked to an increase in the levels of certain molecules in the kidneys. The glomeruli become more 'leaky' as a result of these substances, and albumin leaks into the urine [4]. Proteins in the glomeruli may also get linked as a result of the elevated blood glucose levels.

Proteins that have been "cross-linked" can cause scarring in a specific area. Glomerulosclerosis is the medical term for this scarring of the glomeruli. Glomerulosclerosis normally develops over a period of years, and it only occurs in a small percentage of patients with diabetes. Scar tissue (glomerulosclerosis) eventually replaces healthy kidney tissue as the illness worsens. As a result, the kidneys are unable to perform their vital role of removing waste from the bloodstream. One day this slow 'failure' of the kidneys might lead to what is known as end-stage renal failure [5]. 


\section{MATERIALS AND METHOD}

\section{Data collection techniques}

Before collecting any data, an ethical clearance was obtained from the ethical review board of Federal Teaching Hospital Gombe. Next permission was obtained from the head of chemical pathology department Federal Teaching Hospital Gombe to conduct the study.

\section{Physical Examination}

Analog digital scales were used to weigh and measure the height of each participant. Those who participated in the test were instructed to stand with their feet facing the ceiling or a wall with the knees touching the measurement surface and the buttocks and heels touching the floor. They were also instructed to keep their shoulders relaxed while they stood with their feet pointed outward. Results of the body mass index (BMI) were reported using the formula, $\mathrm{kg} / \mathrm{m} 2$ (weight divided by height squared). Overweight was defined as a BMI of $25 \mathrm{~kg} / \mathrm{m} 2$ or above but less than or equal to $28 \mathrm{~kg} / \mathrm{m} 2$, and obesity was defined as a BMI greater than or equal to $28 \mathrm{~kg} / \mathrm{m} 2$ (World Health Organization WHO 1997 standards).

\section{Collection and Storage of Samples}

A qualified medical laboratory technician drew five millilitres of blood from each research participant using the standard operating procedure guideline. Clots formed after around 30 minutes at room temperature after the blood sample was obtained. Centrifuged blood was centrifuged for 5 minutes at $3000 \mathrm{rpm}$ after clot formation. After that, the serum was isolated from the blood and kept at $20^{\circ} \mathrm{C}$ for further examination. Federal Teaching Hospital and Gombe State University evaluated all samples.

\section{Study Design}

A total of 240 subjects were used for the analysis (200 diabetic and 40 control subjects) and were divided based on their ages and gender. Diabetic patients aged $\geq 18$ years were included in the study.

\section{Statistical Analysis}

SPSS software (version 25.0 for windows; SPSS, Chicago, IL,USA) were used for statistical analysis. Descriptive data were expressed as a mean \pm standard Error of Mean (SEM) and analyzed using one way analysis of variance (ANOVA) followed by post Hoc LSD test (fisher 1935). Multivariate logistic regression models were used to identify the determinant factors associated with diabetes complications. P-value $<0.01$ was considered statistically significant.

\section{RESULTS}

\section{Subjects' characteristics}

Among the 240 subjects, 200 were diabetic and 40 were control subjects, (Table 1) shows the average mean of characteristics of the study subjects; age(years), weight $(\mathrm{kg})$, height(m), and BMI $\left(\mathrm{kg} / \mathrm{m}^{2}\right)$. The body mass index (BMI) of diabetic subjects was highest in diabetic subject than in the control subjects, compared by sex; the BMI was highest in males. Body mass index (BMI) was calculated as the ratio of weight to height squared $\left(\mathrm{kg} / \mathrm{m}^{2}\right)$. Subjects with a BMI $\geq 18 \mathrm{~kg} / \mathrm{m}^{2}$ and $<25 \mathrm{~kg} / \mathrm{m}^{2}$ were classified as normal, a BMI $\geq 25 \mathrm{~kg} / \mathrm{m}^{2}$ and $<28 \mathrm{~kg} / \mathrm{m}^{2}$ were classified as overweight and those with $\mathrm{BMI} \geq 28 \mathrm{~kg} / \mathrm{m}^{2}$ were classified as obese (Table 3) (World Health Organization WHO 1997 standards).

\section{Kidney Indices and Serum Electrolytes}

Data obtained from this study revealed significant increased $(\mathrm{P}<$ 0.01 ) in the serum level of creatinine and urea in the age groups 40-49years, 50-59 years, and 60> above years when compared with the control group (Table 4) The result also indicated a significant increase in the serum level of Chloride $\left(\mathrm{Cl}^{-}\right)$in the age groups 40-49, 50-59 and $60>$ above years when compared with the control group but were higher in males than in females. On the other hand, there was a significant decrease in the serum level of sodium $(\mathrm{Na})$ and bicarbonate $\left(\mathrm{HCO}_{3}\right)$ when compared with the control group (Table 5).

Table 1. Characteristics of the study subject.

\begin{tabular}{|c|c|c|c|c|c|c|}
\hline $\begin{array}{l}\text { Charact- } \\
\text { eristics }\end{array}$ & & $\begin{array}{l}20-29 \\
\text { years }\end{array}$ & $\begin{array}{l}30-39 \\
\text { years }\end{array}$ & $\begin{array}{l}40-49 \\
\text { years }\end{array}$ & $\begin{array}{l}50-59 \\
\text { years }\end{array}$ & $\begin{array}{l}60>\text { above } \\
\text { years }\end{array}$ \\
\hline \multirow{2}{*}{ Age (years) } & Male & $25.3 \pm 0.67$ & $35.25 \pm 0.68$ & $44.50 \pm 0.56$ & $53.80 \pm 0.69$ & $68.65 \pm 1.55$ \\
\hline & Female & $24.7 \pm 0.66$ & $34.05 \pm 0.66$ & $45.20 \pm 0.56$ & $52.95 \pm 0.57$ & $65.55 \pm 0.91$ \\
\hline \multirow[t]{2}{*}{ Weight (kg) } & Male & $61.4 \pm 8.41$ & $74.40 \pm 13.91$ & $70.9 \pm 14.44$ & $69.1 \pm 15.53$ & $69.6 \pm 11.69$ \\
\hline & Female & $68.7 \pm 12.31$ & $72.85 \pm 19.82$ & $74.15 \pm 17.20$ & $67.7 \pm 13.59$ & $69.8 \pm 18.39$ \\
\hline \multirow[t]{2}{*}{ Height (m) } & Male & $1.71 \pm 0.07$ & $1.73 \pm 0.08$ & $1.74 \pm 0.07$ & $1.70 \pm 0.08$ & $1.71 \pm 0.08$ \\
\hline & Female & $1.59 \pm 0.04$ & $1.61 \pm 0.08$ & $1.61 \pm 0.10$ & $1.61 \pm 0.11$ & $1.54 \pm 0.09$ \\
\hline \multirow[t]{2}{*}{$\operatorname{BMI}\left(\mathrm{kg} / \mathrm{m}^{2}\right)$} & Male & $27.0 \pm 1.09$ & $28.07 \pm 1.57$ & $28.4 \pm 1.25$ & $26.35 \pm 1.46$ & $29.4 \pm 1.62$ \\
\hline & Female & $21.0 \pm 0.49$ & $25.15 \pm 1.20$ & $23.3 \pm 1.10$ & $23.78 \pm 1.07$ & $23.8 \pm 0.98$ \\
\hline
\end{tabular}

Table 2. Age and gender of diabetic and control subjects.

\begin{tabular}{lllllll}
\hline $\begin{array}{l}\text { Age } \\
\text { (years) }\end{array}$ & Control & 20-29years & $30-39 y e a r s$ & $40-49 y e a r s$ & $50-59$ years & $60>$ above years \\
Gender & & & & & & \\
\hline Male & $34.10 \pm 1.56$ & $25.30 \pm 0.67$ & $35.25 \pm 0.68$ & $44.50 \pm 0.56$ & $53.80 \pm 0.69$ & $68.65 \pm 1.55^{\mathrm{a}}$ \\
Female & $30.77 \pm 1.59$ & $24.75 \pm 0.66$ & $34.05 \pm 0.66$ & $45.20 \pm 0.56$ & $52.95 \pm 0.57$ & $65.55 \pm 0.91$
\end{tabular}

Table 3. BMI values for diabetic and control subjects

\begin{tabular}{lllllll}
\hline BMI & Control & 20-29years & $30-39 y e a r s$ & $40-49 y e a r s$ & $50-59 y e a r s$ & $60>$ above years \\
& & & & & \\
\hline Male & $20.25 \pm 0.64$ & $27.03 \pm 1.09$ & $28.07 \pm 1.57^{\text {a }}$ & $28.47 \pm 1.25^{\text {a }}$ & $26.35 \pm 1.46^{\text {a }}$ & $29.49 \pm 1.62^{\mathrm{a}}$
\end{tabular}

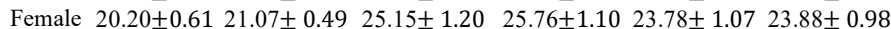

Table 4. Kidney function indices of diabetic and control subjects.

\begin{tabular}{|c|c|c|c|c|c|c|c|}
\hline $\begin{array}{l}\text { Kidney } \\
\text { Function } \\
\text { Indices }\end{array}$ & $\begin{array}{l}\text { Gen } \\
\text { der }\end{array}$ & - Control & $\begin{array}{l}20-29 \\
\text { years }\end{array}$ & $\begin{array}{l}30-39 \\
\text { years }\end{array}$ & $\begin{array}{l}40-49 \\
\text { years }\end{array}$ & $\begin{array}{l}50-59 \\
\text { years }\end{array}$ & $\begin{array}{l}60>\text { above } \\
\text { years }\end{array}$ \\
\hline $\begin{array}{l}\text { Creati- } \\
\text { nine }\end{array}$ & $\mathrm{M}$ & $0.75 \pm 0.02$ & $0.85 \pm 0.04$ & $1.00 \pm 0.06$ & $2.38 \pm 0.08^{\mathrm{b}}$ & $3.56 \pm 0.10^{\mathrm{b}}$ & $6.38 \pm 0.13^{\mathrm{b}}$ \\
\hline$(\mathrm{mg} / \mathrm{dL})$ & $\mathrm{F}$ & $0.70 \pm 0.02$ & $0.68 \pm 0.03$ & $0.89 \pm 0.06$ & $1.93 \pm 0.08^{\mathrm{b}}$ & $3.32 \pm 0.08^{\mathrm{b}}$ & $5.97 \pm 0.09^{\mathrm{b}}$ \\
\hline Urea & M & 28.26 & $28.85 \pm 0.70$ & $29.18 \pm 0.63$ & $89.34 \pm 2.67^{\mathrm{b}}$ & $132.17 \pm 3.01^{\mathrm{b}}$ & $\pm 3.25^{\mathrm{b}}$ \\
\hline (mg/dL) & $\mathrm{F}$ & 27.4 & 27.62 & $28.53 \pm 0.80$ & $85.93 \pm 3.21^{\mathrm{b}}$ & $111.09 \pm 1.77^{\mathrm{b}}$ & $160.56 \pm 3.45^{\mathrm{b}}$ \\
\hline & $\mathrm{M}$ & $139.65 \pm 1.17$ & $138.68 \pm 0.67$ & $137.34 \pm 0.60$ & $120.29 \pm 0.62^{b}$ & $112.88 \pm 0.54^{\mathrm{b}}$ & $102.59 \pm 0.64^{\mathrm{b}}$ \\
\hline$(\mathrm{mmol} / \mathrm{L})$ & & 140.3 & $139.03 \pm$ & $138.54 \pm 0$ & $122.83 \pm$ & $113.03 \pm$ & 102.2 \\
\hline & M & $89.60 \pm 2.13$ & $95.59 \pm 0.97$ & $100.24 \pm 1.87$ & $133.33 \pm 2.58^{b}$ & $163.27 \pm 1.12^{\mathrm{b}}$ & $207.17 \pm 8.23^{b}$ \\
\hline$(\mathrm{mmol} / \mathrm{L})$ & & $84.87 \pm 2.19$ & $87.61 \pm 1.36$ & $95.14 \pm 0.90$ & $124.71 \pm 3.41^{\mathrm{b}}$ & $157.57 \pm 1.45^{\mathrm{b}}$ & $195.20 \pm 6.74^{\mathrm{b}}$ \\
\hline $\begin{array}{l}\mathrm{HCO}_{3}^{-} \\
(\mathrm{mmol} / \mathrm{L})\end{array}$ & & $\begin{array}{l}28.88 \pm 0.47 \\
28.32 \pm 0.66\end{array}$ & $\begin{array}{l}27.69 \pm 0.41 \\
27.01 \pm 0.52\end{array}$ & $\begin{array}{l}27.49 \pm 0.53 \\
26.48 \pm 0.75\end{array}$ & $\begin{array}{l}19.29 \pm 0.28^{b} \\
18.8 \pm 0.28^{b}\end{array}$ & $\begin{array}{l}15.74 \pm 0.23^{\mathrm{b}} \\
15.10 \pm 0.30^{\mathrm{b}}\end{array}$ & $\begin{array}{l}12.03 \pm 0.43^{\mathrm{b}} \\
11.14 \pm 0.39^{\mathrm{b}}\end{array}$ \\
\hline
\end{tabular}

Multivariate Logistic Regression Result

The result shows independent predictor variables by using multivariate adjusted odd ratio for factors predictive or that was associated with the complications of diabetes mellitus in the patients attending FTH hospital Gombe (Table 6). From the result of this study males had 1.449 times (AOR 1.449, $\mathrm{P}<0.046)$ increased odds of having diabetes mellitus over females. While patients aged $>40$ years had 1.6E8 times (AOR 1.6 E8, P<0.997) increased odds over those aged of $<40$ years. Subjects with higher BMI had higher odds of having DM. 
Overweight and obese diabetic patients were 1.381 and 2.048 times (AOR 1.381, $\mathrm{p}<0.01$ for overweight and AOR 2.048, $\mathrm{p}<0.01$ for obesity) respectively more likely to develop diabetes mellitus compared to other diabetic patients. There is association between DM and other complications notably for Kidney indices abnormalities: Creatinine (AOR 43.66, $\mathrm{p}<0.01$ ), urea (AOR $1.122, \mathrm{p}<0.01$ ), and chlorite (AOR 1.126, $\mathrm{p}<0.01$ ).

Table 6. Multivariate adjusted odd ratio ( $95 \%$ confidence interval) for factors predictive of diabetes mellitus complications.

\begin{tabular}{lcclc}
\hline $\begin{array}{l}\text { Explanatory } \\
\text { Variables }\end{array}$ & $\mathrm{B}$ & $\begin{array}{l}\text { Odds } \\
\text { Ratio }\end{array}$ & OR 95\%CI & p value \\
\hline $\begin{array}{l}\text { Male sex } \\
\text { females) }\end{array}$ & (vs. 0.371 & 1.449 & $1.007-2.085$ & 0.046 \\
$\begin{array}{l}\text { Age (years) } \\
20-29\end{array}$ & & & & \\
$30-39$ & -1.386 & 0.250 & $0.115-0.543$ & $<0.01$ \\
$40-49$ & -1.386 & 0.250 & $0.115-0.543$ & $<0.01$ \\
$50-59$ & $21.2031 .6 \mathrm{E} 8$ & $0.00-$ & 0.997 \\
$60>$ above & 21.203 & $1.6 \mathrm{E} 8$ & $0.00-$ & 0.997 \\
Overweight & $21.2031 .6 \mathrm{E} 8$ & $0.00-$ & 0.997 \\
Obesity & 0.323 & 1.381 & $0.788-2.421$ & 0.260 \\
Creatinine & 0.717 & 2.048 & $1.215-3.450$ & 0.007 \\
Urea & 3.776 & 43.662 & $13.258-143.794$ & $<0.01$ \\
$\mathrm{Cl}^{-}$ & 0.115 & 1.122 & $1.068-1.179$ & $<0.01$ \\
& 0.118 & 0.126 & $1.085-1.168$ & $<0.01$
\end{tabular}

\section{DISCUSSION}

Glucose levels in diabetics are abnormally high because of a deficiency in insulin production by the pancreas' B-cells or resistance to the hormone's effects. Insulin is linked to long-term difficulties in the metabolism of carbohydrates, lipids, and proteins [6]. Patients at the Federal Teaching Hospital Gombe, Gombe state, were surveyed in this study to evaluate the prevalence of diabetes and associated consequences.

In this study, there was an equal distribution of age and gender, diabetes mellitus complications increased with advancing age, this could be because aging is often accompanied by decline in lean body mass and increase in body fat particularly by visceral adiposity which may contribute to the development of insulin resistance [7]. Aging is also known to induce a decrease of insulin sensitivity and inadequate response of $\beta$-Cell functional mass when there is insulin resistance [8]. Aging is associated with a decrease of $\beta$-Cell proliferate capacity and enhances sensitivity to apoptosis [9]. Males suffers more from diabetes mellitus complications than females, the explanation for this discrepancy has consistently been fast changing lifestyle due to over whelming influence of Westernization Cum.

Urbanization and with economic and technological development. As men began working in offices, in most developing nations, physical activity among men declined, while women took on more domestic duties and even livestock grazing. As a result of differences in insulin sensitivity between men and women, as well as the consequences of obesity and regional fat deposition, as well as other contributing factors such as high blood pressure and alcohol consumption, male excess in diabetes has been found in many populations with a higher incidence of type 2 diabetes.

Fat tissue influences metabolism by secreting hormones, glycerol, and other compounds such as leptin, cytokines, adiponectin, and proinflammatory molecules, and in obese persons the secretion of these substances will rise. At any weight gain, insulin sensitivity is dictated by the distribution of body fat, and BMI is connected with insulin resistance. Overweight and obesity have been shown to be substantial risk factors for type 2 diabetes, which is consistent with findings reported in many racial/ethnic communities [11].

Because of diabetes, diabetic nephropathy arises. Diabetic complications, such as neuropathy, cardiovascular issues, kidney problems, retinopathy and foot issues are all more likely as the condition progresses according to a recent study conducted by researchers from across the world. Type 1 and type 2 diabetes mellitus can both have diabetic nephropathy [12]. The kidneys of diabetics are permanently damaged by high blood sugar levels, which cause irreparable damage to the kidney's nephrons and microscopic filtering units. As a result, the kidneys are unable to maintain the fluid and electrolyte homeostasis, which is a major symptom of diabetes. The glomerulus removes creatinine from the bloodstream. As the glomerular filtering rate (GFR) decreases, the plasma concentration of serum creatinine and blood urea rises, indicating an increase in glomerular filtration. A high serum creatinine level and a decreased GFR are now considered valid indications of renal disease. Renal impairment in diabetic individuals can be predicted using urea and creatinine serum values [14]. Serum creatinine has a stronger predictive capacity than blood urea in predicting the prognosis of diabetic nephrophathy [15] because of this rise in blood urea and serum creatinine.

A pre-renal issue may be indicated by elevated levels of serum creatinine and blood urea in diabetic individuals, according to another research [16]. According to past research, hyperglycemia is one of the leading causes of renal disease progression [17]. When comparing male and female subjects in this investigation, the serum creatinine levels were found to be higher in men, as reported earlier [18]. The blood levels of sodium and bicarbonate decreased significantly, but the serum levels of chlorite increased significantly. This clearly demonstrated the bicarbonate deficiency caused by its extensive buffering use. $\mathrm{HCO} 3$ serves as a buffer to keep the generation of hydrogen ions in balance. Electrolytes and water are lost through increased urine in DM, causing an imbalance in sodium and potassium levels in the body. Sodium levels in DM were observed to be lower than in the control group in this investigation [20]. Studies have shown that hypovolemic hyponatremia can be caused by osmotic diuresis in patients with uncontrolled diabetes.

Another factor that contributes to the increased renal sodium squandering in diabetic ketoacidosis is a decrease in urine electrolytes. Hypovolemia caused by osmotic dieresis is the most prevalent cause of hypotonic-hyponatremia in people with diabetes [21]. The consequences of diabetes mellitus, such as diarrhoea and vomiting, can also cause hypovolemia. Hyperglycemic hyponatremia, osmotic dieresis-induced hypotonic losses and hypovolemia-induced decreases in blood sodium levels are all factors that contribute to a wide range of serum sodium levels in poorly managed individuals with DM $[21,22]$. Diabetic ketoacidosis has been linked to elevated blood chlorite levels in diabetic individuals. Reduced blood $\mathrm{pH}$ from ketoacidosis leads to an acid-base imbalance and an increase in chlorite. There are several other elements that influence the relationship between blood glucose and serum electrolyte. These include age and the accompanying condition. The result of multivariate logistic regression analyses showed that diabetes was statistically significantly and positively associated with sex, age, overweight, obesity and kidney profile abnormalities. 


\section{CONCLUSION}

From the result of this study, Gender, aging, higher body mass index (BMI), kidney function profile abnormalities were the risk factors associated with diabetes mellitus that led to diabetic nephrophathy which can increase morbidity and mortality in diabetes mellitus. Effective control of blood sugar can stop or prevent the progression of diabetes mellitus to all these complications.

\section{REFERENCE}

1. Diabetes Public Health

Resource.http://www.cdc.gov/diabetes.

2. Indah, M.A. Differential Expression analysis of diabetic related genes in streptozotocin-induced diabetic rat in response to Abelmoschusesculentus treatment. Int Confer Biosci Biochem Bioinfo, 2017;(5),43.

3. Afkarian M, Zelnick LR, Hall YN, et.al. Clinical manifestation of kidney disease among US adults with diabetes. J Am Med Assoc, 2016;316(6):602-610.

4. Kerri L. Cavanaugh, MD. Diabetes management issues for patients with chronic kidney disease. Clin Diabetes, 2007;25(3):90-97.

5. National Kidney Foundation. Clinical practice guidelines and clinical practice recommendations for diabetes and chronic kidney disease. J Am Kidney Dis, 2007;(49):S1-S180.

6. International Diabetes Federation. Global diabetics score card traction progress for action Brussels. Int Diabetics Fed, 2014;P524.

7. Bjorntorp P. Metabolic implication of body fat distribution. Diabetes Care., 1991;14:1132-43.

8. Matveyenko AV, Veldhuis JD, Butler PC. Adaptations in pulsatile insulin secretion, hepatic insulin clearance, and $\beta$-cell mass to agerelated insulin resistance in rats. Am J Physiol Endocrinol Metab. 2008;295(4):E832-41.

9. Menerly GS, Elhoff T. Metabolic alterations in middle aged and elderly obese patients with type 2 diabetes. Diabetes care., 1999;22:112-8.

10. Charitha, B. Arul Singhor, R. Shivashekar, M. \&William, E. Glycated hemoglobin as a dual marker in control glycemic status and diabetic dyslipidemia. Int J Pharm Clin Res, 2013;(5):111-113.

11. Wang, Y. Rimm, E.B. Stampfer, M.J.Willet, W.\& Hu, F.B. Comparison of abdorminal adiposity and overall obesity in predicting risk of the type 2 diabetes among men. J Am Clin Nutr, $2005 ;(8) 1: 558-563$.

12. Ruggenenti P, Remuzzi G. Nephropathy on type and type 2 diabetes, diverse pathophysioogy. J Nephrol Dial Transplant, 2000;15:1990-2.

13. Venugopal, S. \& Iyer, M.U. (). Risk factor analysis and prevalence of micro albuminuria among type 2 diabetes mellitus subjects, the need for screening and monitoring micro albumin. J Asian Exponen Biol Sci, 2010;(1):652-659.

14. Alder, A.1. Stevens, R.J. \& Manley, S.E. (). Development and progression of nephropathy in type 2 diabetes. Int $\mathrm{J}$ Kidney, 2003;(63):225-232.

15. Mittal, A. Sathian, B. Kumar, A. \& Chandrashe kharan, N. Renal disease among Nepalese. J Nepal Epidermiol, 2010;(1), 22-25.

16. Judkay, T. Nutrition for reducing urea and creatinine in blood. J Diabetes Care, 2007;(27):291-2192.

17. Shrestha, S. Gywali, P. Shrestha, R. poundel, sigdel, M. \& Regmi, $P$. Serum urea and creatinine in diabetics and non diabetic subjects. J Clin Diabetes, 2008;(9):11-12.

18. Ashavad, T.F. Todur, S.P. \&Dherai, A.J. Establishement of reference in intervals indians population. J Clin Biochem, 2003;(20):110-118.

19. Kraut J.A and Madians N.E (). Serum anion gap: its uses and limitations in chemical medicine. Clin J Am Soc Nephrol, 2007;2:162-174.

20. Liamis G, Tsimihodimos V, Doumas M, Spyru A, Bairaktari E, Elisaf M, (). A clinical and laboratory characteristics of hypernatraemia in an internal medicine clinic. J Nephrol Dial Transp, 2008;23:136-143.

21. Liamis G, Liberopoulos E, Barkas F, Elisaf M (). Diabetes mellitus and electrolyte disorders. World J Clin Cases, 2014;2:488-496. 